\title{
Monika Kusiak
}

Nancyycielskie Kolegium Jezyków Oboych

Uniwersytet Jagiellonski

\section{INTERDYSCYPLINARNOŚĆ W BADANIACH PROCESU ROZUMIENIA TEKSTU}

\section{Interdisciplinarity in reading comprehension research}

\begin{abstract}
The paper addresses the emergence of interdisciplinarity in humanities research. In the first section, it looks at various conceptions of interdisciplinarity. Then, it discusses an interdisciplinary nature of reading research, overviewing the concept of reading as explored by different fields of science. Finally, as an example of an interdisciplinary study into reading comprehension, the study conducted by the author of the paper is presented. The process of planning and the initial stages of conducting the study are discussed, along with the advantages of drawing on several disciplines in the study.
\end{abstract}

\section{Interdyscyplinarność - definicje}

Pojecie interdyscyplinarności zagościło na dobre w dyskusjach dotyczących różnych dziedzin humanistyki. Poniżej przedstawiono spojrzenie na to zagadnienie proponowane przez Nycza (2006) we „Wprowadzeniu” do „Kulturowej teorii literatury" oraz poglądy Klocha (2007) wygłoszone na ogólnopolskiej konferencji „Interdyscyplinarność w naukach społecznych - możliwość czy powinność". Uwagi Nycza dotyczą przedmiotu poznania literackiego i statusu dyskursu literaturoznawczego, natomiast rozważania Klocha - ogólnie nauk humanistycznych. Wydaje się, że spostrzeżenia obydwu autorów z powodzeniem odnoszą się także do glottodydaktyki - dziedziny, która powstała i czerpie $\mathrm{z}$ teorii oraz wyników badań wielu dziedzin naukowych.

Nycz (2006), przez pojęcie interdyscyplinarności, rozumie wysiłki badawcze podejmowane przez przedstawicieli różnych dyscyplin w celu osiagnnięcia spójnego opisu całej danej dziedziny przedmiotowej. Niestety, autor wyraża 
obawę, że takie rozumienie interdyscyplinarności jest utopia. Nie jest możliwe osiagnięcie zintegrowanego zrozumienia i pełnego, obiektywnego opisu badanych zjawisk. Jednym z powodów tej badawczej niemożności jest „łatwo obserwowalna dziś skłonność do swobodnego wykorzystania narzędzi różnych dyscyplin, w tym literaturoznawstwa" (Nycz 2006: 30). Jako przykład Nycz podaje przyjęcie podstawowych pojęć literaturoznawstwa, takich jak styl, interpretacja, tekst, dyskurs, przez inne dyscypliny nauk humanistycznych i filozofię. Wynikiem tych działań nie jest, jak można byłoby się spodziewać, zintegrowanie wyników badań uzyskanych z różnych punktów widzenia, ale powolne rozpraszanie, nieprzekładalność koncepcji teoretycznych pochodzących z różnych dziedzin nawzajem na siebie. Taki stan ,utopijnej przekładalności” teorii na siebie spowodowana jest, m.in. brakiem jakiegoś języka meta- lub inter- teoretycznego, który pomógłby zintegrować wyniki badań.

Powyższe uwagi o interdyscyplinarności z pewnością odnoszą się do glottodydaktyki. Zapożyczanie pojęć z innych dyscyplin - psychologii, socjologii, literaturoznawstwa czy filozofii - ma miejsce także w glottodydaktyce, zarówno w rozważaniach teoretycznych, jak i działaniach badawczych. „Rozpracowanie” pojęć pochodzących z innych dyscyplin wymaga odpowiedzialności i świadomości naukowej ze strony badaczy, co w rezultacie pomoże doprowadzić nie tylko do stworzenia nowego dyskursu opisującego badaną rzeczywistość, ale także pozwoli na skuteczną wymianę informacji między glottodydaktykami oraz glottodydaktyką a innymi dyscyplinami.

Nycz (2006: 30), na miejsce mało obiecującej interdyscyplinarności, proponuje badania transdyscyplinowe, które polegałyby na ,identyfikacii powinowactw przedmiotowo-problemonych idacych w poprzek (poniżej, pouyziej) istniejacych granic dyscyplinowych" oraz na uchwyceniu podobieństw między porównywanymi dyscyplinami, co w konsekwencji doprowadzi do spojrzenia historycznego na kształtowanie się nowych dyscyplin i pełniejsze zrozumienie stopniowej „rekonfiguracji dyscyplinonych podziatón catego pola bumanistycznej wiedsy" (ibidem). Takie podejście transdyscyplinowe wydaje się być bardzo pomocne w zrozumieniu zmian zachodzących w zakresie glottodydaktyki; historyczne spojrzenie na wpływy różnych dyscyplin na kształtowanie się glottodydaktyki pomoże zwiększyć świadomość badaczy dotyczaca tworzenia nowych koncepcji teoretycznych, metodologii glottodydaktyki i co za tym idzie - używanego dyskursu.

Kolejne rozważanie dotyczy pojęcia transdyscyplinarności. Wg Klocha (2007) transdyscyplinarność jest efektem prac zespołów złożonych z różnych dziedzin nauki, zajmujących się tym samym problemem, np. kompetencja językowa może być badana przez lingwistę, neurologa, specjalistę od chemii mózgu. Tego rodzaju współpraca prowadzi do przeformułowania pytań pojawiających się w obrębie jednej dyscypliny oraz do wypracowania nowych obszarów zainteresowań. W odniesieniu do glottodydaktyki z pewnością taki rodzaj współpracy „wymusza” wypracowanie wspólnych założeń teoretycznych, metodologii oraz dyskursu potrzebnego do wspólnych dyskusji dotyczących pracy i przedstawia- 
nia wyników. Przykładem tego rodzaju wspólnych działań badawczych w ramach glottodydaktyki jest, np. projekt Wilczyńskiej (2002); do adaptowania metodologii $\mathrm{z}$ dziedzin pokrewnych $\mathrm{i}$ testowania ich $\mathrm{w}$ ramach interdyscyplinarnych zespołów badawczych zachęcają Mosorska i Wojciechowska (2008). Podsumowując, jaka pokazuje powyższa dyskusja, interdyscyplinarność stawia przed glottodydaktyką nowe wyzwania. Czerpanie z koncepcji teoretycznych metodologii innych dyscyplin wymaga od badaczy wyraźnego zdefiniowania ,zapożyczonych” pojęć oraz określenia obszarów „wykorzystywanych” teorii.

\section{Interdyscyplinarność $\mathrm{w}$ badaniach dotyczących procesu rozumienia tekstów}

W badaniu zaplanowanym i przeprowadzanym przez autorkę artykułu interdyscyplinarność jest rozumiana jako triangulacja czyli badanie danego zagadnienia z różnych perspektyw. W badaniu triangulacja dotyczy teorii czyli porównania interpretacji danych z różnych perspektyw teoretycznych (tzw. triangulacja teorii - Konarzewski, 2002) oraz użytych metod badawczych czyli porównanie danych zebranych różnymi metodami (tzw. triangulacja metod - Konarzewski, 2002).

Interdyscyplinarny charakter ww. badań polegał także na zaczerpnięciu inspiracji z różnych dziedzin w czasie planowania badań. W poniższej części przedstawione są dziedziny nauki, których przedmiotem badań jest czytanie. Dziedziny te koncentrują się zarówno na procesach mentalnych zachodzących w czasie przetwarzania tekstu, jak i na samym tekście. Chciałabym zaznaczyć, że poniższa dyskusja opiera się na skromnym wyborze dziedzin i tematów, które są badane w zakresie tych dyscyplin. Sa to zagadnienia, które zainteresowały mnie na etapie planowania moich badań i które ze względu na teorie lub metodologię stanowiły do nich inspirację.

\subsection{Sprawność czytania i jej interdyscyplinarny charakter}

Czytanie jest przedmiotem badań filologów (np. teorie narracji) i filozofów (np. estetyka recepcji). Szczególnie zainteresowały mnie perspektywa fenomenologiczna Isera (1976) oraz poglądy Umberta Eco (2007). Obaj autorzy w swoich teoriach dotyczących czytania podkreślają rolę czytelnika w interpretacji tekstu. Znaczenie tekstu jest tworzone przede wszystkim przez czytelnika. Eco (2007) ukazuje proces czytania jako grę, w którą jest wciagany czytelnik. W celu wyjaśnienia relacji czytelnik-tekst autor proponuje pojęcie Czytelnika Modelowego; jest to zbiór tekstualnych instrukcji czytania, pewien rodzaj genetycznego wyposażenia, który czytelnik otrzymuje w tekście. Takie spojrzenie na czytanie i czytelnika zwróciło moją uwagę na możliwość zbadania interpretacji, tzn. na możliwość obserwacji jak poszczególni czytelnicy odczytują znaczenie tekstu i porównanie ich technik interpretacji z zachowaniem Czytelnika Modelowego. 
Kolejną dyscypliną badającą czytanie jest szeroko pojęte językoznawstwo. Swoimi badaniami dziedzina ta obejmuje przede wszystkim tekst i jego właściwości, np. bada wyznaczniki tekstowości, takie jak kohezja i koherencja (np. Wilkoń, 2002) czy analizuje struktury tekstowe (np. van Dijk i Kintsch, 1983). Lingwiści tekstu zajmują się także interakcją między tekstem a czytelnikiem, np. analizują strategiczne pozycje w tekście, tzn. sygnały, które ułatwiają czytelnikowi odbiór tekstu. Związek między strukturą tekstu a kontekstem ${ }^{1}$ (który oddziałuje na poziom gramatyczny i pragmatyczny tekstu) uwypuklili Halliday i Hassan (1985) w swojej gramatyce funkcjonalnej, podkreślając równocześnie społeczne uwarunkowania tworzenia i odbioru tekstów. W tym miejscu dyskusji warto wspomnieć o współczesnych gramatykach tekstu, które koncentrują się nie tylko na analizie struktury tekstu, ale również na relacji między strukturą tekstu a procesami odbywającymi się w umyśle czytelnika. Na szczególną uwagę zasługuje model przetwarzania tekstu Ann Gernsbacher (1990) i teorie rozumienia tekstu ekspozycyjnego Bruce'a Brittona (1994). Obie teorie łącza koncepcje językoznawcze (analiza struktury tekstu) z psychologicznymi (badanie procesu czytania). W moim badaniu ww. teorie wyznaczyły kierunek skonstruowania narzędzia do analizy tekstów wykorzystywanych w badaniu oraz technik służących do analizy relacji studentów dotyczących ich procesu czytania.

Badania w zakresie psychologii czytania skoncentrowały się, m.in. na obserwacji i opisie strategii używanych w czasie czytania (np. Block, 1986; Chodkiewicz, 2000; Hosenfeld, 1977; Droździał-Szelest, 1997). Droździał-Szelest (1997) zidentyfikowała strategie uczenia się stosowane przez uczniów szkół średnich, w tym również te dotyczące sprawności czytania. Celem badań Chodkiewicz (2000) było zbadanie, czy możliwe jest przyswojenie słownictwa pojawiającego się $\mathrm{w}$ tekście w czasie czytania nastawionego na zrozumienie. Interesującym etapem badania było prześledzenie zmian zachodzących w wiedzy leksykalnej badanych studentów. Badania Hosenfeld (1977) i Block (1986) pozwoliły wyodrębnić zachowania „lepszych” i „gorszych” czytelników.

Sprawność czytania jest także przedmiotem badań specjalistów zajmujacych się edukacją. W Polsce badania dotyczące alfabetyzmu funkcjonalnego wśród dorosłych prowadzone przez Białeckiego (1996) oraz wśród młodzieży w ramach Programu Międzynarodowego Oceny Umiejętności Uczniów (OECD/PISA 2000 r.) świadczą o niedostatecznym przygotowaniu Polaków do odbioru tekstów pisanych.

Badania w zakresie socjologii wzbogacają nasze spojrzenie na temat roli czytania w społeczeństwie. Przykładem mogą być badania Davida Bartona prowadzone w Wielkiej Brytanii dotyczące czytelnictwa. Barton (1994) zastanawia się nad czynnikami wpływającymi na różne „praktyki” czytelnicze, np. nad rola,

${ }_{1}$ Pojęcie kontekstu jest szeroko opisywane przez językoznawców. Różnice między sytuacją a kontekstem zostały szczegółowo omówione, np. przez Żydek-Bednarczuk (2005: 229). 
jakie czytanie odgrywa w życiu różnych społeczności lub czynnikami społecznymi (ideologiami) wpływającymi na proces nauczania czytania.

Kolejna perspektywa badawcza, warta omówienia w tej dyskusji, to teorie kulturowe. Tekst jest postrzegany jako produkt kultury, a czytanie wymaga rozumienia socjokulturowych implikacji obecnych w tekście oraz odniesienia tekstu do tła społecznego i kulturowego. Takie spojrzenie na tekst i czytanie podkreśla potrzebę doskonalenia kompetencji interkulturowej czytelnika oraz umiejętności krytycznego odbioru tekstu, polegającej m.in. na świadomości czytelnika dotyczącej możliwości zaistnienia konfliktu między jego stylem czytania a intencją autora tekstu oraz między jego wiedzą o świecie a reprezentacją świata przedstawioną przez autora. Badaczami promującymi takie podejście są np. Johns (1997), McCormick (1994); a w Polsce, m.in. Kusiak i Bandura (2007).

Ta dyskusja byłaby bardzo niekompletna bez omówienia wpływu współczesnych teorii krytyki literackiej na teorie i koncepcje dydaktyczne dotyczące doskonalenia sprawności czytania w warunkach szkolnych. Myrdzik (1999), Pilch (2004) i Hobot (2004) podkreślają zalety zastosowania w praktyce szkolnej poststrukturalistycznych metod badawczych, takich jak hermeneutyka, intertekstualność czy dekonstrukcja. Wpływ tych metodologii zauważa się również w podręcznikach szkolnych, pisanych często przy współudziale pracowników naukowych (Pilch, 2004: 175). Pilch (2004) proponuje hermeneutykę wg Gadamera jako metodę interpretowania tekstów poetyckich. Nauczyciel powinien wykorzystać polisemiczność tekstu i zarysować uczącym się kilka alternatyw jego interpretacji. Cytując Ricoeura (1989), Pilch traktuje tekst jako zapis muzyczny, a czytelnika jako dyrygenta orkiestry, który postępuje zgodnie $z$ instrukcjami partytury i który poprzez odczytania znaków partytury nadaje utworowi brzmienie. Badania intertekstualne i intersemiotyczne zachęcają do postrzegania tekstu jako dialogowego nawiązania do innych tekstów oraz do odnajdowania jego odniesień intersemiotycznych. Wydaje się, że współczesne poststrukturalistyczne metody badawcze stanowia ciekawa alternatywę dla dydaktyki kształtowanej przez strukturalizm, który jako metoda badawcza promował budowanie „całościowych, uporządkowanych interpretacji” (Hobot, 2004: 174).

Podsumowując, czytanie i tekst sa przedmiotem badań wielu dyscyplin nauki. Każda $z$ ww. perspektyw kładzie nacisk na inny aspekt czytania, zachęcając dydaktyków do urozmaicenia swojego repertuaru metod nauczania, a badaczy do czerpania inspiracji dotyczących koncepcji teoretycznych i stosowanej metodologii. Spojrzenie na czytanie w interdyscyplinarny sposób wzbogaca możliwości dydaktyczne. Np. zamiast tradycyjnych ćwiczeń sprawdzających zrozumienie tekstu, nauczyciel może zaproponować uczącym się analizę tekstu wg gramatyki funkcjonalnej Hallidaya (technika opisana przez Wallace, 2003). Cennym ćwiczeniem byłoby zachęcenie czytelników do szukania nawiązań do innych tekstów oraz doskonalenie czytania krytycznego i kompetencji interkulturowej. Uczniowie mogą zostać poproszeni o określenie Czytelnika Modelowego (pojęcie proponowane, m.in. przez Eco) oraz określenie swojego repertuaru 
wiedzy, przekonań i umiejętności oraz porównanie ich z repertuarem Czytelnika Modelowego. Innym ćwiczeniem może być obserwowanie własnych strategii czytania lub strategii stosowanych przez innych czytelników. Jeśli chodzi o wpływ perspektywy interdyscyplinarnej na działanie badawcze, jako przykład badania o charakterze interdyscyplinarnym, zainspirowanego przez różne dyscypliny, poniżej przedstawiam opis badania, którego przedmiotem jest rozumienie tekstu przez studentów studiów neofilologii.

\section{Opis badania o charakterze interdyscyplinarnym dotyczącego rozumienia tekstu}

Należy podkreślić, że tekst znajduje się w centrum współczesnych koncepcji kształcenia językowego, zarówno tego dotyczącego języka rodzimego (polskiego), jak i obcego. Podkreśla się rolę nauczania czytania ze zrozumieniem w przygotowaniu uczących się do świadomego uczestnictwa i refleksyjnego odbioru dziel kultury (np. Kowalikowa, 2004). Jednym z argumentów uzasadniającym podjęcie problemu rozumienia tekstów pisanych są moje dotychczasowe doświadczenia dydaktyczne. Długoletnie obserwacje studentów neofilologii sugerują zmiany dotyczące roli, jaką teksty pisane odgrywają w procesie uczenia się. Zmieniły się również studentów dotyczące, np. typów działań dydaktycznych, które towarzyszą tzw. pracy z tekstem. Dotychczasowe badania w tym zakresie (Kusiak i Bandura, 2007), opisujące próby zmiany relacji dydaktycznej i komunikacyjnej z jednoprzedmiotowej na wielopodmiotowa, wydają się wskazywać na problemy studentów w prowadzeniu argumentacji i wspólnym dochodzeniu do interpretacji i ewaluacji tekstu.

Opisywane badanie pozwoli na spojrzenie na proces rozumienia tekstu $z$ dwóch perspektyw: indywidualnej i interpersonalnej. Celem części badającej indywidualny wymiar rozumienia tekstów jest obserwacja różnic indywidualnych w procesie czytania, tzn. tego, jak czytający realizuja swoje indywidualne cele interpretacyjne w sytuacji komunikacyjnej, jaką jest czytanie, wykorzystując swój indywidualny repertuar wiedzy i umiejętności. Punktem wyjścia tej części badania było proste pytanie wypływające $z$ praktyki dydaktycznej: czy jest jakiś aspekt czytania, w którym studenci są lepsi w języku rodzimym niż obcym i który można by udoskonalić w języku obcym? W celu osiagnięcia tego celu badani studenci zostana poproszeni o czytanie dwóch tekstów - najpierw w języku polskim, potem w języku angielskim i równocześnie opisywanie procesu czytania tekstów (jest to metoda głośnego myślenia, ang. thinking aloud). Wynikiem analizy będzie także określenie możliwości transferu strategii czytania między językami, np. między językiem rodzimym a obcym.

Badanie interpersonalnego wymiaru rozumienia tekstów obejmuje obserwację i analizę dyskursu - procesu „kolektywnego” rozumienia tekstu obcojęzycznego, tzn. konstruowania przez studentów ich indywidualnych reprezentacji czytanego tekstu w czasie dyskusji (interakcji) z innymi czytającymi. Badanie to 
oznacza analizę procesów, którym podlegają wszyscy uczestnicy dyskusji, tzn. przebiegu budowania znaczeń indywidualnych i „kolektywnych” poprzez negocjację relacji i ról między uczestnikami dyskusji.

Warto podkreślić, że połączenie tych dwóch perspektyw - psychologicznej (wymiar indywidualny czytania) i socjologicznej (wymiar interpersonalny czytania) zapewni triangulację metod, czyli zastosowanie różnych metod badawczych w celu dokładniejszego zbadania czynników wpływających na proces rozumienia tekstu.

\subsection{Zalety korzystania $\mathrm{z}$ różnych dyscyplin $\mathrm{w}$ ww. badaniu}

$\mathrm{Na}$ różnych etapach opisywanego badania pomocne okazały się różne dyscypliny nauki, o których pisałam we wcześniejszej części artykułu. Przedmiotem badania jest rozumienie tekstów ekspozycyjnych (argumentacyjnych). Do lepszego zrozumienia specyfiki tego rodzaju tekstu przyczyniły się opracowania polskich językoznawców, np. Wilkonia (2002), poświęcone funkcjonowaniu mechanizmów spójnościowych w wypowiedziach rozważająco-komentujących oraz charakterystyka Żydek-Bednarczuk (2005) dotycząca tekstów o funkcji informacyjnej. Niezwykle cenne okazały się też gramatyki tekstu ekspozycyjnego, takie jak model mentalny van Dijka i Kintscha (1983) i model Ann Gernsbacher (1990), a w szczególności teoria rozumienia tekstów ekspozycyjnych Brittona (1994). Wszystkie wymienione teorie wyjaśniają relację między struktura tekstu a procesami mentalnymi czytelnika. Britton (1994) zakłada istnienie związku między treściami, które autor chce przekazać w tekście a organizacja struktur tekstowych, które powinny pomóc czytelnikowi w stworzeniu mentalnej reprezentacji tekstu. Czytelnik otrzymuje zdania, a jego celem jest zbudować sieć idei. Teoria Brittona posłużyła w badaniu do stworzenia narzędzia do analizy tekstów czytanych przez studentów oraz do analizy protokołów studentów odzwierciedlających ich proces czytania tekstów. Analiza protokołów polegała nie tylko na wyodrębnieniu strategii używanych przez czytelników, ale również na spojrzeniu na czytanie tekstu jak na proces tworzenia reprezentacji mentalnej (modelu) tekstu i obserwacji jak czytający konstruują swoje modele czytanego tekstu. Zarówno teksty, jak i reprezentacje mentalne tekstu zanalizowano pod kątem treści. Oznaczało to wyodrębnienie w tekstach i reprezentacjach stworzonych przez studentów propozycji (jednostek znaczenia) i porównanie zawartości propozycjonalnej z tych dwóch kontekstów. Podejście to pozwoliło na połączenie następujących perspektyw badawczych:

- językowej, która pomogła prześledzić zależność między językowa struktura tekstu a rozumieniem tekstu;

- poznawczej, która polegała na zbadaniu interakcji między nadawca i odbiorca, obserwacji jak czytelnicy, prowadzeni przez wewnątrztekstowe sygnały, konstruuja globalny sens tekstu oraz w jaki sposób ich reprezentacje tekstu różnią się od tej „zamierzonej” przez nadawcę. 


\subsection{Dalsze wyzwania dotyczące badania}

W dalszej części pracy opracowania wymaga przede wszystkim drugi etap badania, skupiający się na interpersonalnym wymiarze rozumienia tekstu. Istotne będzie lepsze określenie produktu wspólnego czytania, „kolektywnego” rozumienia tekstu, zdefiniowanie „wiedzy” dotyczącej tekstu, która jest wynikiem budowania znaczeń indywidualnych i „kolektywnych” poprzez negocjację znaczeń dotyczących rozumienia tekstu oraz negocjacji relacji i ról między uczestnikami dyskusji. W celu zbadania procesu negocjacji i konstruowania rozumienia tekstu konieczne jest wyodrębnienie etapów tworzenia rozumienia, np. proponowanie interpretacji, negocjacje, odrzucanie znaczeń, itp. Z pewnością pomocną metoda badawczą okaże się analiza konwersacyjna oraz analiza treści ukierunkowana na zbadanie procesu tworzenia „kolektywnej” reprezentacji umysłowej dotyczącej czytanego i dyskutowanego tekstu. Kolejnym krokiem w badaniu będzie scharakteryzowanie studentów jako szkolnej społeczności „czytelniczej”, tzn. określenie tekstów, jakie czytaja na zajęciach, poznanie ich oczekiwań dotyczących czytania oraz zbadanie roli, jaką przypisuja swojej edukacji polonistycznej. Taka określenie pozwoli na lepszą interpretację wyników badania.

\section{Podsumowanie}

W opisanym badaniu wyraźnie zarysowały się dwie perspektywy: psychologiczna, koncentrująca się na analizie procesu tworzenia reprezentacji mentalnej tekstu poszczególnych studentów oraz socjologiczna, badająca proces tworzenia „kolektywnego" rozumienia tekstu. W procesie planowania badania zainspirowały mnie następujące dyscypliny:

- teorie krytyki literackiej oraz filozofie dotyczące recepcji tekstu, m.in. Isera i Eco, które zwróciły moją uwagę na konieczność zbadania interpretacji - w moim badaniu analizowanej jako reprezentacja tekstu tworzona przez czytelnika;

- gramatyki tekstu oraz teorie wyjaśniające rozumienie tekstów ekspozycyjnych, które pozwoliły mi lepiej poznać specyfikę tego typu tekstu i w rezultacie pomogły opracować narzędzia analizy tekstów wykorzystywanych w badaniu oraz techniki umożliwiające porównanie treści tekstu z treścią reprezentacji tworzonej przez czytających;

- teorie socjologiczne, które zachęciły mnie do zbadania reguł „kolektywnego" tworzenia rozumienia tekstu; socjologiczna perspektywa będzie także pomocna w scharakteryzowaniu badanych jako członków zinstytucjonalizowanej wspólnoty o pewnym sposobie czytania.

Mam nadzieję, że cel naukowy badania przełoży się na rzeczywiste praktyki dydaktyczne. Wyniki badania dostarczą wskazówki na wypracowanie nowych technik doskonalenia sprawności czytania tekstów obcojęzycznych na 
poziomie zaawansowanym, m.in. pozwolą na określenie cech dyskursu szkolnego, tworzonego przez nauczyciela i uczących się w czasie dyskusji dotyczących rozumienia tekstów.

\section{BIBLIOGRAFIA}

Barton, D. 1994. Literacy. Oxford: Blackwell.

Białecki, I. 1996. „Alfabetyzm funkcjonalny”. Res Publica 6: 68-76.

Britton, B.K. 1994. „Understanding expository text. Building mental structures to induce insights" (w) Handbook of psycholinguistics (red. Morton A. Gernsbacher). San Diego: Academic Press: 641-674.

Block, E.L. 1986. „See how they read: comprehension monitoring of L1 and L2 readers". TESOL Quarterly 26(2): 319-343.

Chodkiewicz, H. 2000. Vocabulary acquisition from the written context. Inferring word meaning by Polish learners of English. Lublin: Maria Curie-Skłodowska University Press.

Dijk van, T.A. i W. Kintsch. 1983. Strategies of discourse comprehension. New York: Academic Press.

Droździal-Szelest, K. 1997. Language learning strategies in the process of acquiring a foreign language. Poznań: Motivex.

Eco, U. 2007. Sześć przechadzęe po lesie fikciji. Kraków: Wydawnictwo Znak.

Gernsbacher, M.A. 1990. Language comprehension as structure building. Hillsdale: N.J.: Lawrence Erlbaum Associates.

Halliday, M.A.K. i R. Hasan. 1985. Language, context and text: Aspects of language in a social - semiotic perspective. Victoria: Deakin University Press.

Hobot, J. 2004. „Poststrukturalne kierunki badawcze w szkolnej praktyce polonistycznej, czyli o zwiazkach teorii literatury i metodyki" (w) Polonista w szkole. Podstawy kszztatcenia naucsyciela polonisty (red. A. Janus-Sitarz). Kraków: Universitas: 173-189.

Hosenfeld, C. 1977. „A preliminary investigation of the reading strategies of successful and non-successful second language learners". System 5(2): 110-123.

Iser, W. 1976. The act of reading. Baltimore: The Johns Hopkins University Press.

Johns, A.M. 1997. Text, role and context. Developing academic literacies. Cambridge: Cambridge University Press.

Kloch, Z. 2007. Interdyscyplinarność w naukach humanistycznych - Tekst wygłoszony na ogólnopolskiej konferencji „Interdyscyplinarność w naukach społecznych - możliwość czy powinność" zorganizowanej w Instytucie Filozofii i Socjologii PAN (21 listopada 2007). http://www.obta.uw.edu. $\mathrm{pl} / \mathrm{pl} /$ node/61DW 13.10.2009.

Konarzewski, K. 2002. Jak uprawiać badania oświatowe. Metodologia praktyczna. Warszawa: Wydawnictwo Szkolne i Pedagogiczne.

Kowalikowa, J. 2004. „Tekst cudzy - tekst własny” (w) Pryygotowanie ucrnia do odbioru różnych tekstón kultury (red. A. Janus-Sitarz). Kraków: Universitas: 15-53. 
Kusiak, M. i E. Bandura. 2007. „Facilitating educated talk while working with written texts in an academic foreign language classroom" (w) PASE Papers 2007. Vol. 1: Studies in language and methodology of teaching foreign languages (red. J. Arabski, D. Gabryś-Barker i A. Łyda). Katowice: University of Silesia: 309-328.

McCormick, K. 1994. The culture of reading and the teaching of English. Manchester: Manchester University Press.

Mosorska, E. i B. Wojciechowska. 2008. „Rzetelność i efektywność badań rozwoju osobistej kompetencji komunikacyjnej w ustnych interakcjach obcojęzycznych". Neofilolog 31: 41-49.

Myrdzik, B. 1996. „O hermeneutyce w perspektywie edukacji polonistycznej (część II)”. Jesy)k polski w sækole średniej 4 (1995/1996): 45-51.

Nycz, R. 2006. „Wprowadzenie” (w) Kulturowa teoria literatury. Gtónne pojecia $i$ problemy (red. M. P. Markowski i R. Nycz). Kraków: Universitas: 5-38.

Pilch, A. 2004. „Hermeneutyka jako metoda interpretowania tekstów poetyckich" (w) Polonista w szkole. Podstany kształcenia nauczyciela polonisty (red. A. Janus-Sitarz). Kraków: Universitas: 191-215.

Ricoeur, P. 1989. Jezylk, tekst, interpretacja. Warszawa: PIW.

Wallace, C. 2005. Critical reading in language education. London: Palgrave. Macmillan.

Wilczyńska, W. 2002. Autonomizacja w dydaktyce jesylkón obcych. Doskonalenie sie w komunikagï ustnej. Poznań: Wydawnictwo Naukowe UAM.

Wilkoń, A. 2002. Spójność i struktura tekstu. Kraków: Universitas.

Żydek-Bednarczuk, U. 2005. Wprowadzenie do lingwistycznej analizy tekstu. Kraków: Universitas. 